\title{
NEUROSAINS DALAM MENGEMBANGKAN KECERDASAN INTELEKTUAL PESERTA DIDIK SD ISLAM AL-AZHAR BUMI SERPONG DAMAI
}

\author{
${ }^{1}$ Susanto, ${ }^{2}$ Ida Royani Munfarohah \\ ${ }^{1}$ Pascasarjana Institut PTIQ Jakarta, ${ }^{2}$ Pascasarjana Institut PTIQ Jakarta \\ ${ }^{1}$ Email: susanto.kaisar@gmail.com, ${ }^{2}$ Email: idaroyani@gmail.com
}

\begin{abstract}
Neuroscience in developing intellectual intelligence is crucial to known by all teachers. Because, nervous system structure is underlying human action in terms of cognitive, affective, and pshycomotoric. So, teachers easier in developing intelligence by using fun and interesting learning method. This research purpose is to know and to search information related to neuroscience in developing students' intellectual intelligence at Al-Azhar Islamic Elementary School Bumi Serpong Damai. This research type is descriptive qualitative by using phenomenology method. To reach this purpose researcher has interviewed five teachers as core informant and one principal as supporting informant. Moreover, researcher also observed and study documents. The research result show that neuroscience can be developing students' intellectual intelligence at Al-Azhar Islamic Elementary School Bumi Serong Damai. This matter indicated by students are more enthusiastic in learning, active in asking, think more divergent, and also higher learning motivation during learning process. So, students be able to learn without coercion, earnestly and learning process occur with pleasure.
\end{abstract}

Keyword : Neuroscience, Intellectual Intelligence, Students

\begin{abstract}
ABSTRAK
Neurosains dalam mengembangkan kecerdasan intelektual peserta didik sangat penting untuk diketahui oleh semua guru. Karena, struktur sistem saraf mendasari tindakan manusia baik dari aspek kognitif, afektif, dan psikomotorik agar guru lebih mudah dalam mengembangkan kecerdasan intelektual melalui metode pembelajaran yang menarik dan menyenangkan. Penelitian ini bertujuan untuk mengetahui dan mencari informasi terkait dengan neurosains dalam mengembangkan potensi kecerdasan peserta didik di Sekolah Dasar Islam Al-Azhar Bumi Serpong Damai. Jenis penelitian ini adalah deskriptif kualitatif. Dengan menggunakan metode phenomenology. Untuk meneliti tujuan tersebut peneliti melakukan interview kepada 5 guru kelas sebagai informan inti dan kepala sekolah sebagai informan pendukung. Selain itu, peneliti juga melakukan observasi atau pengamatan, dan juga melakukan studi dokumen. Hasil penelitian menunjukkan bahwa neurosains dapat mengembangkan kecerdasan intelektual peserta didik Sekolah Dasar Islam Al-Azhar Bumi Serpong Damai. Hal ini ditunjukkan dengan peserta didik yang lebih antusias mengikuti pembelajaran, peserta didik aktif bertanya, lebih berfikir divergen, dan juga memiliki motivasi belajar yang tinggi selama proses pembelajaran. Sehingga, peserta didik mampu belajar tanpa paksaan, dengan sungguhsungguh, dan pembelajaran berlangsung menyenangkan.
\end{abstract}

Kata Kunci : Neurosains, Kecerdasan Intelektual, Peserta Didik 


\section{PENDAHULUAN}

Menjadi orang tua adalah kesempatan mulia, menjadi orang tua berarti telah Tuhan beri kepercayaan untuk memiliki anak sebagai titipan. Tugas orang tua selanjutnya adalah mengasuh, menjaga, merawat, dan membesarkan anak-anaknya dengan usaha yang terbaik. Bagi para orang tua anak merupakan harta yang paling berharga, mereka akan memberikan cinta, kasih sayang, perhatian yang tidak kurang-kurang. Warisan terbaik bagi anak dari orang tuanya adalah ilmu salah satu cara orang tua mewujudkan supaya anaknya berilmu ialah dengan menempuh pendidikan. Jika saat ini hak anak-anak adalah bermain, kelak saat dewasa mereka akan dihadapkan dengan berbagai pilihan dan kesulitan yang akan dihadapinya disinilah peran orang tua dan ilmu sangat dibutuhkan. Suatu saat mereka mungkin akan gundah saat ingin memilih sekolah, atau memilih jurusan yang akan dipilih saat kuliah. Tugas orang tua adalah membimbing dan mengarahkan potensi yang dimiliki anak-anaknya.

Pendidikan merupakan upaya pewarisan nilai-nilai yang akan menjadi penolong dan sebagai penuntun dalam menjalani kehidupan. Pendidikan juga sekaligus memperbaiki nasib serta peradaban umat manusia. Pendidikan merupakan aset penting bagi kemajuan bangsa. Pendidikan memegang peranan penting dalam menentukan kualitas warga negaranya, karena kualitas warga negara akan menentukan ke arah mana negara tersebut akan bergerak. Setiap warga negara wajib mengikuti jenjang pendidikan, baik jenjang pendidikan usia dini, pendidikan dasar, pendidikan menengah, maupun tinggi.

Negara telah mengatur hak bagi setiap warga negara untuk mendapatkan pendidikan sebagai sarana untuk meningkatkan kualitas hidupnya yaitu pada UUD pasal $28 \mathrm{C}$ ayat 1 dan 2 dan pasal 31 ayat 1 dan 2. Dalam UUD 1945 pasal 31, ayat 5 menyebutkan, "Pemerintah memajukan ilmu pengetahuan dan teknologi dengan menunjang tinggi nilai-nilai agama dan persatuan bangsa untuk kemajuan peradaban serta kemajuan umat manusia." Dalam pembukaan UUD 1945 alinea ke-4 juga memuat salah satu tujuan bangsa Indonesia, yaitu mencerdaskan kehidupan bangsa. Tertulis jelas dalam Undang-Undang No. 20 tahun 2003, Pasal 3: "Pendidikan nasional berfungsi mengembangkan kemampuan dan membentuk watak serta peradaban bangsa yang bermartabat dalam rangka mencerdaskan kehidupan bangsa, bertujuan untuk berkembangnya potensi peserta didik agar menjadi manusia yang beriman dan bertaqwa kepada Tuhan Yang Maha Esa, berakhlak mulia, sehat, berilmu, cakap, kreatif, mandiri, dan menjadi warga negara yang demokratis serta bertanggung jawab." Perserikatan Bangsa Bangsa (PBB) melalui lembaga UNESCO (United Nation Educational Scientific and Cultural Organisation) mencanangkan empat pilar pendidikan baik untuk masa sekarang maupun masa depan, yakni:(1) learning to know, (2) learning to do, (3) learning to be, (4) learning to live together. Keempat pilar pendidikan tersebut menggabungkan tujuan-tujuan IQ, EQ, dan SQ.

Pendidikan adalah sarana terbaik untuk menciptakan suatu generasi baru, pemuda pemudi yang tidak hanya cerdas secara emosi dan spiritual tetapi sekaligus tidak menjadi bodoh dan terbelakang secara intelektual dalam pendidikan atau tidak menyadari adanya perkembangan dalam setiap cabang pengetahuan manusia. Ilmu pengetahuan adalah jembatan menuju masa depan yang lebih baik, memperoleh kehidupan yang lebih baik dan juga mampu membawa bangsa kita ini bersaing dengan negara-negara maju lainnya. Ilmu Pengetahuan dan Teknologi atau disingkat dengan IPTEK selalu menjadi bagian terpenting dalam mendorong perkembangan sebuah negara. Generasi yang akan datang harus menjadi generasi yang seluruhnya menguasai ilmu pengetahuan dan teknologi. Teknologi informasi yang perkembangannya sangat cepat itu memerlukan sumber daya manusia yang berkualitas. Generasi muda ini diharapkan menjadi penerus dalam mengembangkan kemajuan ekonomi di masa yang akan datang. IPTEK merupakan tulang punggung pembentukan ekonomi yang menjadi kekuatan utama dalam persaingan global dan sarana mencapai kemakmuran bangsa. Berbekal keyakinan ini, negara Barat dan Macan Asia seperti Jepang, Korea Selatan, dan Taiwan yang konsisten mengerahkan sejumlah besar dana para ilmuwannya, berlomba 
menguasai IPTEK. Dari sana akan muncul inovasi yang diterapkan industri untuk meningkatkan daya saing produk dan meraup devisa. Proses ini bermuara untuk meningkatkan kualitas hidup dan kesejahteraan bangsa.

Dunia tidak pernah berhenti menawarkan perubahan secara berkala maka kita perlu menerimanya dan harus mampu beradaptasi agar bisa bertahan dalam persaingan yang amat ketat. Memperluas wawasan dapat membuka dunia baru sehingga mudah bagi kita untuk mempelajari banyak hal dan perubahan yang terjadi. Itulah mengapa kita perlu menambah wawasan setiap harinya. Memperluas wawasan akan semakin membuka pikiran kita bahwa dunia ini sangat luas. Dengan mengembangkan kecerdasan intelektual dapat menumbuhkan imajinasi, dengan berimajinasi akan mengasah kecerdasan intelektual dengan berimajinasi kita akan membayangkan banyak hal dan mulai berpikir secara rinci terkait langkah-langkah apa saja yang perlu dilakukan untuk meraih apa yang kita inginkan. Semakin imajinatif diri kita, maka kita akan semakin membuka diri untuk menciptakan teknik pemecahan masalah yang inovatif dan efektif, terampil dalam bertukar pikiran, dan terampil dalam berkoneksi dengan orang banyak.

Perkembangan IPTEK di Indonesia sudah mulai mengikuti perkembangan namun masih tergolong sangat jauh perkembangan-nya bila dibandingkan negara-negara lain. Seperti halnya di Negara Amerika, Rusia, China mereka kini mulai memproduksi barang-barang yang sangat canggih seperti robot yang bisa melakukan pekerjaan manusia, serta dikembangkan juga Pembangkit Listrik Tenaga Nuklir yang kita ketahui manfaatnya begitu besar bagi kehidupan sehari-hari. Dari berbagai perkembangan IPTEK yang terjadi, itu semua merujuk pada tujuan utama yaitu perubahan kehidupan masa depan yang lebih baik. Disinilah peran pendidikan untuk mengembangkan dan meningkatkan kecerdasan intelektual peserta didik. Bagaimana pendidikan memberi motivasi dan mampu menumbuhkan kesadaran peserta didik bahwa ilmu itu penting, ilmu adalah sebuah kebutuhan, dan menjadikan belajar sebagai gaya hidup.

Di dalam Al-Qur'an dijelaskan bahwa Allah akan mengangkat kedudukan orang yang beriman dan berilmu dibandingkan yang hanya sekedar beriman tanpa ilmu. Manusia diciptakan dengan segala kesempurnaannya, dan Allah SWT memberikan akal pada manusia untuk membedakan dengan makhluk hidup lainnya. Dengan akal tersebut manusia diwajibkan mencari ilmu pengetahuan dan memiliki ilmu pengetahuan dalam segala hal agar tidak tersesat dalam menjalani kehidupan. Ilmu pengetahuan ibarat sebuah cahaya yang akan menuntun manusia. Ilmu pengetahuan merupakan bekal bagi manusia untuk mencapai sukses dunia dan akhirat. Al-Qur'an sangat membenci kebodohan. Wahyu yang pertama kali turun dalam AlQur'an adalah QS. Al-Alaq. Wahyu pertama ini perlu menjadi renungan dan dikaji maknanya. Terlebih kata pertama dari ayat ini. Sebuah kata yang pertama menghujam di hati Rasulullah SAW. Allah memilih kata ini dalam bentuk motivasi pada satu hal, yaitu ilmu dan Allah memilih satu metode kajian ilmu yaitu membaca sebagai metode belajar Rabbani.

Rasulullah sebagai figur sentral telah memberikan tauladan dalam mendidik dan membimbing dengan langsung mengajar. Selain menjadi pendidik upaya Rasulullah dalam memberikan pendidikan dengan memanfaatkan tawanan perang untuk mengajar baca tulis, kemudian mengirimkan para sahabat ke daerah-daerah yang baru masuk Islam. Beberapa Hadits Rasulullah yang memotifasi umatnya untuk terus belajar seperti hadits yang diriwayatkan Ibnu Abdil Barr yang menjelaskan bahwa mencari ilmu merupakan kewajiban untuk laki-laki dan perempuan. Isyarat hadits ini memberi gambaran bahwa dalam ajaran Islam laki-laki dan perempuan mempunyai potensi dan kesempatan yang sama untuk mendapatkan ilmu pengetahuan. Hal ini dibuktikan dengan peranan Aisyah. Kecerdasan dan keluasan ilmu Aisyah tidak hanya dalam ilmu agama, tetapi Aisyah mampu dalam ilmu-ilmu umum seperti syair, sastra, sejarah, kedokteran dan ilmu-ilmu lain. Aisyah juga menjadi rujukan keilmuan setelah wafatnya Rasulullah SAW. Aisyah menjadi bukti sosok perempuan dengan tingkat 
intelektual yang melebihi kebanyakan laki-laki. Bahkan, para sahabat laki-laki Nabi sering memuji kecerdasan Aisyah.

Aisyah merupakan figur perempuan cerdas di masa Rasulullah SAW, dia mampu meriwayatkan hadits sebanyak 2210 hadits dan menjadi rujukan dan tempat bertanya para sahabat pasca Rasulullah SAW wafat. Selain kewajiban yang sama dalam mencari ilmu, terdapat hadits Rasulullah yang memerintahkan umatnya untuk belajar sampai negeri Cina. Walaupun pada masa Rasulullah Cina belum menjadi negara adidaya seperti sekarang, akan tetapi keluasan berfikir dan keterbukaan wawasan Rasulullah SAW untuk kemajuan umat mengisyaratkan umatnya untuk terus berkembang dan menjadi pribadi yang unggul. Hal ini dapat terbukti di jaman kejayaan Islam selama tiga setengah abad mampu menaklukan wilayah utara sampai ke spanyol wilayah barat dan melalui Persia sampai ke India Timur dan berjayanya kekuasaan Islam dan ilmu pengetahuan. Salah satu konsep pendidikan yang dijalankan Rasulullah adalah memberikan kesempatan belajar tidak hanya pada usia produktif dan bersifat formal, Rasulullah juga memerintahkan untuk pendidikan sepanjang hayat mulai buaian sampai liang lahat. Pesan yang disampaikan Rasulullah ini mencerminkan adanya optimisme dalam menggali ilmu dan menjadikan ilmu sebagai penuntun hidup umatnya sepanjang masa.

Islam sebagai agama pembawa misi rahmatan lil alamin sangat menekanan agar manusia melaksanakan amanahnya untuk menggerakkan segala potensinya karena ia sebagai khalifah di bumi. Amanah itu ialah bagaimana manusia mampu memahami rahasia Illahi yang disimpan dibalik jagad raya ini. Untuk itulah sebagai makhluk yang sempurna diantara makhluk yang lainnya Allah menitipkan akal untuk berfikir, hati untuk berbudi, dan menitipkan jasmani untuk berkreasi sehingga mampu menemukan rahasia dibalik ciptaanNya. Akal manusia akan berfugsi apabila terdapat rangsangan-rangsangan indrawi yang merupakan sumber ilmu pengetahuan yang akan diolah oleh akal. Otak berfungsi menyimpan pengetahuan, menambah wawasan, mendapatkan pengetahuan yang baru, dapat memahami sesuatu dengan pemaknaan yang lebih dalam, dapat meningkatkan pengetahuan. Otak dapat berubah secara positif jika dihadapkan pada lingkungan yang diberi rangsangan positif, demikian juga sebaliknya otak akan menjadi negatif jika tidak diberi rangsangan. Dengan olah akal inilah manusia mampu menciptakan ilmu pengetahuan yang akan menjawab semua misteri dibalik jagad raya ini. Sedangkan hati berusaha mengontrol dan mempengaruhi akal untuk senantiasa ingat keagungan Tuhannya dan jasmani berupaya mengimplementasikan dari kerja otak dan hati. Disinilah pentingnya suatu pendidikan bagi manusia. Pendidik harus mampu menghadirkan lingkungan belajar yang mampu merangsang peserta didik untuk mengaktifkan otaknya.

Selanjutnya jika dicermati kata-kata atau pertanyaan yang dipakai dalam Al-Qur'an untuk menggambarkan perbuatan berfikir, bukan hanya memakai kata "aqala" tetapi juga Iqra memiliki arti pokok menghimpun, selain itu berarti pula menyampaikan, menelaah, membaca, mendalami, meneliti dan mengetahui ciri-cirinya. Al-Qur'an juga menyampaikan gagasanya agar manusia menghimpun berbagai informasi melalui pengamatan atau Nadzara; yaitu melihat secara abstak dalam arti berfikir dan merenung. Al-Qur'an menyuruh manusia untuk intizar terhadap alam semesta, makhluk hidup dan makhluk yang tidak bernyawa dengan jaminan hukum-hukum yang ditetapkan Allah (sunatullah) tidak akan berubah. Tadabbara yaitu merenungkan sesuatu yang tersurat dan tersirat. Al-Qur'an mengajak manusia untuk menyelidiki, dan juga mengungkapkan keajaiban alam serta berusaha memanfaatkan seluruh kekayaan alam yang melimpah ruah untuk kesejahteraan hidup, Tafakkara yaitu berfikir secara mendalam, dan yang terakhir Tazakkara; yang berarti mengingat, memperoleh peringatan, mendapatkan pelajaran, memperhatikan dan mempelajari, semuanya mengandung berfikir dalam mengembangkan ilmu pengetahuan.

Belajar adalah salah satu aktivitas peserta didik yang terjadi di dalam lingkungan belajar sebagai tahap awal memperoleh ilmu pengetahuan. Tujuan belajar peserta didik adalah untuk 
memperoleh pengetahuan yang tercantum dalam hasil belajar yang optimal sesuai dengan kecerdasan intelektual yang dimilikinya. Di era reformasi ilmu pengetahuan dan teknologi, perbaikan kegiatan pembelajaran harus diupayakan secara maksimal agar mutu pendidikan meningkat, hal ini dilakukan karena majunya pendidikan membawa implikasi meluas terhadap pemikiran manusia dalam berbagai bidang sehingga setiap generasi muda harus belajar banyak untuk menjadi manusia terdidik sesuai dengan tuntutan zaman. Berhasilnya suatu tujuan pendidikan bergantung bagaimana proses pembelajaran yang dialami oleh peserta didik. Namun sayangnya dalam prosese pembelajaran sering ditemukan beberapa masalah diantaranya; banyaknya peserta didik yang mengantuk saat proses pembelajaran sedang berlangsung, tidak fokus, berkurangnya motivasi peserta didik untuk berpartisipasi dalam belajar, banyaknya peserta didik yang membolos pada saat jam pelajaran dimulai, prestasi peserta didik yang rendah karena tidak menyerap pembelajaran secara maksimal. Hal ini bisa disebabkan karena proses pembelajaran kurang menarik dan menyenangkan sehingga peserta didik tidak tertarik mengikuti proses pembelajaran, atau ikut dalam pembelajaran nanmun tidak fokus dalam proses pembelajaran. Tugas seorang guru dalam hal ini adalah bagaimana seorang guru mampu membuat proses pembelajaran lebih menarik dan menyenangkan. Seorang guru harus mampu memberikan stimulas-stimulasi agar otak sebagai alat untuk berfikir dapat diaktifkan terlebih dahulu sebelum memulai proses pembelajaran sehingga peserta didik tertarik dan mengikuti proses pembelajaran secara optimal. Pembelajaran tidak mungkin akan berlangsung dengan baik jika otak belum diaktifkan atau harus dilakukan stimulasi terlebih dahulu.

Penelitian menunjukkan bahwa manusia belum optimal dalam mengembangkan otaknya dalam berbagai hal baik untuk memecahkan masalah, menemukan gagasan baru, ide, kreativitas, dan inovasi. Sejauh ini sistem pendidikan di sekolah-sekolah mengabaikan cara kerja sistem limbik sebagai pusat emosi yang belum dilibatkan dalam pembelajaran, padahal pusat emosi ini berhubungan erat dengan penyimpanan memori jangka panjang. Pengabaian terhadap sistem limbik membuat proses pembelajaran menjadi mati dan juga tidak menarik, banyak ditemukannya pesera didik yang tertidur saat proses pembelajaran sedang beralangsung. Lebih dari itu pemanfaatan seluruh bagian otak (whole brain) secara terpadu belum diaplikasikan dengan efektif dalam sistem pendidikan. Neurosains perlu diterapkan dalam proses pembelajaran karena dinyatakan mampu mengaktivasi otak, mempengaruhi emosi, meningkatkan keterampilan sosial, dan motivasi. Melibatkan peserta didik untuk belajar melalui aktivitas merupakan pilar yang sangat penting dalam mengkonstruksi pengetahuan, perasaan, kemauan, dan keterampilan.

Neurosains adalah ilmu yang mempelajari tentang otak dan sistem saraf. Otak mengatur seluruh fungsi tubuh, mengendalikan kebanyakan perilaku dasar manusia seperti makan, tidur, belajar. Otak bertanggung jawab atas penciptaan peradaban, seni, ilmu, bahasa, dan lain-lain. Pendidik umumnya jarang memperhatikan permasalahan ini. Pengabaian terhadap sistem limbik mengakibatkan matinya suasana pembelajaran. Sistem dan objek tidak mampu berjalan sempurna tanpa adanya subjek. Subjek disini adalah pendidik yang memahami pembelajaran yang dilakukan. Semakin memahami neurosains maka tujuan pendidikan akan lebih mudah tercapai. Selama ini pendidikan tidak menaruh perhatian yang serius terhadap neurosains padahal ini sangat penting dalam memaksimalkan fungsi otak, lebih dari itu, neurosains menjadi alat untuk mengembangkan kurikulum bila dilihat integrasi pengembangan neurosains dalam pembelajaran telah menghasilkan berbagai teori belajar berbasis otak. Otak merupakan tumpuan bagi perasaan dan perilaku. Otaklah yang menerima dan mengalami peristiwa, segala sesuatu berawal dan berakhir di otak, cara kerja otak menentukan kualitas hidup manusia yang baik yang meliputi tingkat kebahagiaan, kualitas hubungan dengan orang lain, dan keberhasilan dalam profesi. Otak mengatur seluruh fungsi tubuh, mengendalikan kebanyakan perilaku dasar manusia mulai dari makan, minum, tidur, menghangatkan tubuh, dan lain sebagainya. 
Untuk menjadi seorang yang sukses dengan kecerdasan intelektual yang tinggi, kita perlu memberikan upaya yang kuat untuk mencapainya. Pastikan bahwa impian ini bukan sekedar omong kosong belaka. Buktikan dengan mencari input-input baru yang bermanfaat bagi kita untuk dijadikan fondasi yang kuat di masa depan. Salah satu inputnya adalah dimulai dari guru. Salah satu elemen penting dalam pendidikan adalah guru karena ia bertugas untuk mengajar, mendidik, melatih, membimbing, mengarahkan, menilai, dan mengevaluasi muridmuridnya di sekolah. Sehingga sekolah-sekolah harus memiliki guru yang berkualitas. Salah satu kunci Finlandia menjadi negara dengan sistem pendidikan terbaik di dunia adalah karena memiliki guru yang berkualitas.

Guru berperan penting dalam upaya mengembangkan potensi peserta didik. Guru menurut UU no 14. Tahun 2005 "adalah pendidik profesional dengan tugas utama mendidik, mengajar, membimbing, mengarahkan, melatih, menilai, dan mengevaluasi peserta didik pada pendidikan anak usia dini jalur pendidikan formal, pendidikan dasar, dan pendidikan menengah." Guru merupakan pelaku utama dalam penerapan program pendidikan di sekolah serta memiliki peran yang sangat penting mencapai tujuan pendidikan yang diharapkan. Guru dapat mengembangkan potensi kecerdasan peserta didik dengan cara menciptakan suasana pembelajaran yang menyenangkan dan dapat dinikmati peserta didik. Pembelajaran yang memberikan kesempatan kepada peserta didik untuk bermain dan beraktivitas, memberi suasana aman dan bebas secara psikologis, penerapan disiplin yang tidak kaku, memberi keluasan pada peserta didik untuk boleh memiliki ide, gagasan, atau pendapat sendiri, mampu memotivasi peserta didik berpartisipasi secara aktif, dan memberi kebebasan berpikir kreatif.

Tujuan pembelajaran di sekolah hakikatnya adalah membantu peserta didik untuk mengembangkan potensinya secara optimal, oleh karena itu dalam hal ini guru dan sekolah berperan sangat penting menjadi fasilitator bagi peserta didik. Sebagai fasilitator guru harus menggunakan pendekatan belajar aktif, yaitu dengan cara guru mendorong peserta didik menemukan makna sendiri melalui pemecahan masalah secara riil agar peserta didik mengkonstruksi pengetahuannya sendiri. Pembelajaran aktif akan memberikan ruang yang cukup bagi prakarsa, kreativitas, dan kemandirian sesuai dengan bakat, minat, dan perkembagan fisik serta psikologis peserta didik. Guru harus memiliki metode mengajar yang mampu mengembangkan kecerdasan intelektual peserta didik. Metode adalah jalan yang harus ditempuh dalam rangka memberikan sebuah pemahaman terhadap murid tentang pelajaran yang mereka pelajari. Metode sangat penting dan harus dimiliki seorang guru sebelum memasuki ruang belajar. Metode sangat berpengaruh besar dalam pengajaran dengan metode pembelajaran dapat sukses atau gagal. Oleh karena itu metode sangat berperan penting dalam pendidikan, karena metode merupakan pondasi awal untuk mencapai suatu tujuan pendidikan dan asas keberhasilan sebuah pembelajaran.

Faktor intelektual merupakan salah satu faktor yang berperan dalam proses pembelajaran. Dengan kemampuan intelektual yang cukup seseorang dapat mengikuti proses pembelajaran dengan baik. Kemampuan intelektual manusia tersebut tidak lepas dari keberadaan suatu unsur yang sangat vital yaitu otak. Kemampuan belajar dan mengelolola informasi pada manusia merupakan ciri penting yang membedakan antara manusia dan makhluk lain, kemampuan belajar itu memberi manfaat bagi individu dan juga masyarakat untuk menempatkan diri dalam makhluk yang berbudaya, dengan belajar seseorang mampu merubah perilaku, dan membawa perubahan pada individu-individu yang belajar, yang memiliki pengetahuan, sikap, dan keterampilan. Otak manusia terdiri dari 100-200 milyar sel neuron yang siap memproses trilyun informasi, akan tetapi umumnya $5-10 \%$ bisa memanfaatkan untuk mengakses informasi, hal ini disebabkan saraf di otak tidak terbiasa terlatih. Kemampuan otak untuk berpikir atau bernalar sangat ditentukan oleh kebiasaan kita melatihnya, ia sama halnya dengan otot yang kita miliki, kelenturan otot disebabkan gerakan yang teratur dan terbiasa. Bagi seseorang yang memaksa ototnya bekerja di luar kebiasaan akan 
terasa pegal dan sakit. Demikian halnya dengan otak, seseorang yang tidak terbiasa membaca buku maka matanya akan mudah lelah, mengantuk. Otak manusia berpikir tidak hanya ditentukan oleh kecerdasan dan kepintaran seseorang, akan tetapi kebiasaan ia memaksimalkan otaknya untuk berpikir dan bernalar. Orang pintar yang tidak biasa berpikir dan bernalar tak ubahnya seperti sebilah pisau yang tajam yang mampu membelah kaleng, jika terkena air maka lama kelamaan akan tumpul, maka ia membutuhkan perawatan dan pengasahan agar tetap tajam. Dari keterangan tersebut dapat diketahui bahwa perkembangan faktor intelektual manusia sangat erat kaitannya dengan upaya untuk melatih kemapuan otak. Jika seorang terbiasa memaksimalkan fungsi otaknya maka kemampuan intelektualnya akan berkembang. Perkembangan ini tentu saja tidak terjadi dengan sendirinya melainkan membutuhkan proses latihan yang dilakukan secara berkesinambungan. Dengan demikian, dalam proses belajar sudah seharusnya peran faktor intelektual ini mendapat perhatian dari pendidik agar dapat dikembangkan dengan maksimal.

Oleh sebab itu, neurosains sangat perlu untuk diperkenalkan kepada masyarakat luas. Edukasi ilmu pengetahuan baru ini sangat bermanfaat bagi pengembangan potensi peserta didik. Semakin memahami pembelajaran berbasis neurosains maka tujuan pendidikan akan sampai, sebaliknya tidak memahami pembelajaran neurosains maka tujuan tidak sampai. Secara filosofis, hakikat pendidikan adalah membentuk manusia sempurna atau insan kamil dimana manusia berkembang seluruh potensi atau kecedasannya, baik potensi jasmani, rohani, maupun akal. Adapun alasan peneliti memilih sekolah SD. Islam AL-Azhar BSD adalah (1) karena sekolah tersebut sudah menerapkan neurosains dalam mengembangkan potensi kecerdasan peserta didik. (2) para guru di sekolah ini melibatkan sistem limbik sebagai pusat emosi dalam pembelajaran, (3) para guru memiliki metode pembelajaran yang bersifat fun learning sehingga mampu dinikmati oleh peserta didik, dan melibatkan keaktifan, dan kreativitas siswa dalam pembelajaran.

\section{METODE PENELITIAN}

Metode yang digunakan dalam penelitian ini adalah dengan menggunakan metode survey dengan pendekatan fenomenologi. Sumber data dalam penelitian ini adalah kata-kata, tindakan, dan dokumen. Sedangkan objek analisis dari penelitian ini adalah orang-orang yang terlibat dalam pelaksanaan im-plementasi neurosains dalam mengembangkan kecerdasan intelektual peserta didik, yaitu orang-orang yang benar-benar me-ngetahui, mengalami, dan memahami aktifitas yang terjadi di SD ISLAM AL-AZHAR BSD. Obyek analisis penelitian ini meliputi:

a. Tenaga pengajar guru kelas 1-6 (6 orang).

b. Kepala sekolah (informan pendukung).

c. Peserta didik.

Metode pengumpulan data dalam penelitian ini penulis terjun langsung pada objek penelitian untuk mendapatkan data yang valid. teknik pengumpulan data dalam penelitian ini terdiri dari:

a. Wawancara adalah bentuk komunikasi dua orang, melibatkan seseorang yang ingin memperoleh informasi dari seorang lainnya dengan mengajukan pertanyaan, berdasarkan tujuan tertentu. ${ }^{1}$ Menurut Burhan Bungin wawancara adalah proses percakapan dengan maksud untuk mengkonstruksi mengenai orang, kejadian, kegiatan, organisasi, motivasi, perasaan, dan sebagainya yang akan dilakukan dua pihak yaitu pewawancara (interviewer) yang mengajukan pertanyaan dengan orang yang diwawancarai (interviewee). ${ }^{2}$ Metode ini digunakan untuk memperoleh informasi mengenai peran neurosains dalam mengembangkan

\footnotetext{
${ }^{1}$ Deddy Mulyana, Metodologi Penelitian Kualitatif, cet. VII, Bandung: PT. Remaja Rosdakarya, 2010, hal 180.

${ }^{2}$ Burhan Bungin, Metode Penelitian Kualitatif, Depok: PT. Raja Grafindo Persada, 2017, hal 155.
} 
kecerdasan intelektual peserta didik SD AL-AZHAR BSD secara lebih mendalam. Adapun yang menjadi informan dalam penelitian ini adalah 3 guru kelas, 1 guru agama, dan 1 guru olahraga/ guru kesenian, dan kepala sekolah sebagai informan pendukung.

b. Metode observasi adalah alat pengumpulan data yang dilakukan dengan cara mengamati dan mencatat secara sistematik gejala-gejala yang diselidiki. ${ }^{3}$ Dalam hal ini, peneliti melakukan observasi pada proses pembelajaran di kelas. Observasi pada saat pembelajaran ini adalah untuk mengetahui pembelajaran berbasis otak/neurosains dalam mengembangkan kecerdasan intelektual peserta didik oleh guru. Teknik ini mampu memberikan deskripsi yang faktual, cermat dan terinci mengenai keadaan di lapangan.

c. Studi Dokumen merupakan pelengkap dari penggunaan teknik pengumpulan data selain melalui wawancara dan observasi dalam penelitian kualitatif, karena hasil penelitian dari kedua teknik tersebut akan lebih kredibel atau dapat dipercaya jika didukung oleh dokumen. ${ }^{4}$ Melalui metode dokumentasi, peneliti dapat menggali data berupa dokumen terkait pembelajaran, diantaranya: seperti silabus, RPP, dokumen penilaian, dan buku acuan pembelajaran.

\section{PENELITIAN DAN PEMBAHASAN}

\section{Dipertajam data temuan penelitian}

Dalam penelitian ini peneliti telah melakukan observasi, studi dokumen, mewawancarai 1 orang kepala sekolah sebagai informan pendukung, dan kepada 5 guru sekaligus melakukan pengamatan kepada peserta didik kelas 1-6 tentang implementasi neurosains dalam mengembangkan kecerdasan intelektual peserta didik di SD Al-Azhar dengan hasil sebagai berikut:

1. Menurut kepala sekolah SD Al-Azhar Drs. H Dedy Hidayat "upaya yang dilakukan dalam mempersiapkan guru melaksanakan tugas pembelajaran dengan melakukan supervisi perencanaan, pengorganisasian, pengarahan, dan pengawasan kepada dewan guru. Dengan cara memantau edukasi yang dilakukan oleh guru dan kesiapan guru dalam mengajar seperti melakukan monitoring pada tahap perencanaan proses pembelajaran meliputi unsur silabus dan rencana pelaksanaan pembelajaran (RPP) yang memuat identitas mata pelajaran, standar kompetensi (SK), kompetensi dasar (KD), indikator pencapaian kompetensi, tujuan pembelajaran, materi ajar, alokasi waktu, metode pembelajaran, kegiatan pembelajaran, penilaian hasil belajar, dan sumber belajar.

Selain itu dilakukan monitoring tenaga pendidik dalam mengenali karakter peserta didiknya, mengembangkan tenaga pendidik, mengadakan rapat secara periodik, meningkatkan kompetensi pedagogik guru dan mengembangkan kurikulum pembelajaran. Cara yang digunakan kepala sekolah dalam meningkatkan kompetensi pedagogik para guru adalah dengan cara memberikan mereka berbagai macam pelatihan, khsusunya bekal-bekal dalam proses pembelajaran."

2. Menurut bapak Endang Sugilar "dalam menyampaikan materi pelajaran kesenian, kesulitan pasti ada karena kondisi masing-masing peserta didik pasti berbeda, minat dan bakat dari peserta didik juga berbeda, dalam hal penyerapan materi masing-masing peserta didik memiliki inteligensi yang berbeda-beda. Menurut bapak Endang dibutuhkan waktu sekitar dua sampai tiga bulan untuk mengetahui karakter dari masing-masing peserta didik, dari pengalamannya mengajar beliau menemukan ada peserta didik yang memiliki bakat di bidang seni, ada juga yang lebih tertarik pada bidang selain seni, olahraga misalnya. Namun pak Endang memahami dari segi kesukaan dan bakat yang dimiliki oleh peserta didiknya. Beliau mengembangkan potensi peserta didik sesuai dengan bakat dan minatnya. Cara yang

\footnotetext{
${ }^{3}$ Cholid Narbuka dan Abu Achmadi, Metodologi Penelitian; cet. VII, Jakarta: Bumi Aksara, 2005, hal. 70.

${ }^{4}$ Sugiyono, Metode Penelitian Kuantitatif, Kualitatif, dan R\&D; cet. XIV, Bandung: Alfabeta, 2006 , hal 240.
} 
dilakukan pak Endang terhadap peserta didik yang kurang tertarik dengan musik adalah dengan memotivasi peserta didiknya agar peserta didiknya mampu menyelesaikan setiap tugas yang diberikan oleh sekolah. Dalam mengajar beliau menyampaikan materi dimulai dari materi yang mudah terlebih dahulu kemudian bertingkat ke materi selanjutnya. Dalam mengajar pak Endang mengajak peserta didiknya untuk menghafal karena merupakan pelajaran praktik musik, mengajak peserta aktif, menganalisa dengan memberikan stimulasi-stimulasi, dan pada akhir pelajaran selalu mengadakan refleksi agar materi yang dipelajari dapat diserap secara efektif.

3. Menurut pak Abi Hurairah dalam menyampaikan materi pelajaran agama tidak mengalami kesulitan dalam menyampaikan materi namun hanya butuh pengelolaan kelas saja, bagaimana beliau mengatur peserta didik agar fokus terlebih dahulu sehingga mereka mampu berkonsentrasi dari awal hingga akhir pem-belajaran. Langkah awal yang dilakukan pak Abi dalam memulai pembelajaran adalah dengan melakukan apresiasi, mengambil fokus dan perhatian peserta didik terlebih dahulu, setelah mereka fokus barulah memulai pembelajaran. Selain itu pengenalan terhadap karakter peserta didik juga diperlukan. Waktu fokus untuk anak sekolah dasar adalah sekitar 10-15 menit jadi dilakukan selingan terlebih dahulu agar mereka tidak jenuh dan kembali fokus pada pembelajaran. Pak Abi menggunakan berbagai metode agar peserta didik tidak merasa jenuh, dan dapat tersambung antara materi yang satu dan materi yang lainnya. Memberikan motivasi menggunakan tayangan vidio-vidio. Pak Abi menggunakan pendekatan student oriented dan teacher oriented secara bergantian tergantung mana yang lebih dibutuh-kan. Dalam pembelajaran pak Abi membiarkan peserta didik mengeeksplorasi dan menganalisa pengetahuan sendiri. Pak Abi berperan sebagai fasilitator. Pada akhir pembelajaran pak Abi melakukan refleksi agar pengetahuan yang disampaikan dapat dimengerti dan dipahami dengan jelas.

4. Menurut Ibu Sri sebagai guru kelas dan guru bidang studi dalam menyampaikan materi tidak mengalami kesulitan karena mengajar pada kelas unggulan. Menurutnya memahami karakter peserta didik itu sangat penting, cara yang dilakukan untuk mengetahui karakter peserta didiknya yaitu dengan melakukan pemetaan karakter anak dan melihat dalam proses pembelajaran. Motivasi juga sangat dibutuhkan untuk peserta didik agar bersemangat dalam proses pembelajaran. Dalam menghadapi suatu masalah guru menelaah terlebih dahulu permasalahannya kemudian memberikan masukan atau stimulus kepada peserta didik untuk menyelesaikan permasalahannya. Dengan menggunakan metode tanya jawab maka peserta didik akan terstimulasi untuk meng-eksplor pengetahuannya, beliau juga memahami sisi emosi peserta didik dalam pembelajaran, memberikan motivasi. Jika peserta didik membutuhkan bantuan untuk menyelesaikan masalah maka guru akan membantu menyelesaikan masalahnya. Pembelajaran berlangsung sesuai dengan RPP yang telah dibuat namun bersifat fleksibel. Setiap 10-15 menit harus dilakukan metode yang berbeda. Pembelajaran berlangsung dua arah student oriented dan teacher oriented setelah itu di akhir pembelajaran selalu dilakukan refleksi agar pengetahuan yang telah diperoleh dapat diserap secara optimal.

5. Menurut Ibu Asih sebagai guru kelas dan guru bidang studi dalam menyampaikan materi kesulitan pasti ada karena kondisi peserta didik yang heterogen untuk mengatasinya dengan cara mengganti metode pembelajaran. Dalam memahami karakter peserta didik dilakukan pengamatan setiap harinya, misalkan hari pertama melakukan observasi kepada peserta didik absen nomor 1-5, namun jika hari itu absen nomor 10 memerlukan perhatian maka fokus penilaian karakter dialihkan terlebih dahulu kepada nomor absen 10. Mengobservasi juga masalah-masalah yang mungkin timbul dari rumah dan juga masalah kesehatannya, maka ibu Asih harus secepat mungkin merespon emosi yang sedang dialamai oleh peserta didik. Selain itu pemberian motivasi dilakukan dengan mengajarkan peserta didik untuk menyayangi diri sendiri karena jika kita pintar maka kita sendiri yang akan menikmatinya. 
Beliau juga memberi contoh kesuksesan yang diraih oleh para tokoh terkenal untuk memotivasi peserta didik. Beliau juga membiarkan peserta didiknya untuk menganalisa setiap masalah sehingga mampu menyelesaikannya. Baik teacher oriented maupun student oriented kedua pendekatan ini dilakukan secara bersamaan, pada akhir sesi pembelajaran refleksi sangat perlu dilakukan untuk mengukur sejauh mana pemahaman yang diperoleh peserta didik.

6. Menurut ibu Dayu dalam menyampaikan materi kesulitan selalu ada sebagai guru harus mampu memilih metode yang tepat untuk mengatasi kesulitan. Dalam olah raga menggunakan metode ice breaking untuk kelas 1 dan 2 karena rasa ingin bermain mereka masih besar jadi bagaimana mengelola belajar sambil bermain. Misalkan materi lari atau lompat digunakan metode bermain untuk merangsang motorik peserta didik. Dalam memahami karakter peserta didik harus menambah ilmu misalnya ada anak yang sangat suka bola dan hanya ingin belajar menggunakan bola maka dipilih metode agar peserta didik mau bermain tanpa bola. Bermain sambil belajar merupakan motivasi agar peserta didik menyukai belajar. Pendekatan dalam mengajar bergantian student and teacher oriented tergantung pendekatan mana yang lebih dibutuhkan, mengajar sambil mengasuh peserta didiknya. Jika setelah selesai permainan ada peserta didik yang terganggu emosinya karena merasa kalah dalam permainan maka guru melakukan refleksi bahwa dalam perlombaan selalu ada yang kalah dan menang, jadi peserta didik tidak membawa emosi negatif dan kembali lagi ceria agar dapat memulai pelajaran kembali dengan senang hati.

Berdasarkan hasil wawancara yang telah dilakukan, peneliti memiliki analisis bahwa para guru di SD. Islam Al-Azhar sudah mengimplementasikan neurosains dalam mengembangkan kecerdasan intelektual peserta didik. Hal ini terbukti dari cara pembelajaran mereka yang menggunakan kinerja otak peserta didiknya dengan baik, mengajarkan mereka berpikir kreatif dan menghadapi persoalan-persoalan penting, serta menanamkan kebiasaan untuk berpikir. Sistem pembelajaran tentang pencapaian intelektual yang berasal dari partisipasi aktif merasakan pengalaman yang bermakna, pengalaman yang memperkuat hubungan antara sel-sel otak yang sudah ada dan membentuk hubungan saraf baru dapat membantu peserta didik mengembangkan potensi kecerdasan mereka. Mengembangkan model pembelajaran kolaboratif dan kooperatif sehingga peserta didik memiliki pengalam belajar yang bermakna, mampu berpikir kritis, kreatif, inovatif, dan mampu menyelesaikan masalah. Pembelajaran yang berlangsung sesuai kompetensi abad 21 atau dikenal dengan $4 \mathrm{C}$, yaitu (1) communicative (2) collaborative, (3) critical thinking dan problem solving, (4)creative dan innovative.

Dalam cortex cerebri terdapat sistem limbik yang berfungsi sebagai pengatur emosi dan memori emosional. Para guru memahami peran emosi dalam pembelajaran sangatlah penting. Maka para dewan guru dan wali kelas saling bersinergi untuk berusaha mewujudkan pembelajaran yang meyenangkan dan melibatkan emosi. Misalkan jika ada peserta didik yang marah setelah kalah dalam permainan olah raga guru berperan menasehati, "Nak ini hanya permainan tidak apa-apa ada yang kalah dan ada yang menang" sehingga peserta didik kembali tersenyum dan mengikuti pelajaran dengan ceria kembali. $80 \%$ guru mengakui kesulitan pasti ada dalam menyampaikan materi pembelajaran kepada peserta didik dikarenakan kondisi peserta didik yang berbeda baik dari segi intelektual, psikologis, dan perbedaan lainnya. Namun tidak semua peserta didik hanya berkisar 1 sampai 2 peserta didik. Namun para guru berusaha mengkondisikan kelas, membuat pembelajaran dapat berlangsung secara efektif. Sisanya sebanyak 20\% mengatakan tidak mengalami kesulitan dalam menyampaikan materi karena mengajar di kelas unggulan. Guru mengatakan jika harus mengajar di kelas anak-anak yang unggul dalam bidang akademis tidak mengalami kesulitan menyampaikan materi namun dalam proses pembelajaran para dewan guru selalu menyampaikan motivasi baik berupa pujian, ataupun reward agar peserta didik semakin semangat dalam belajar. 
Lingkungan belajar di sekolah ini sangat baik terlihat dari kondisi sekolah yang nyaman untuk belajar, lokasi yang bersih, lingkungan kelas yang tertata rapi, dan dilengkapi dengan media belajar yang memadai. Para guru yang mengajar melakukan apresiasi yang sangat menarik perhatian peserta didik dahulu agar mau fokus kepada guru. Jenis soal yang guru berikanpun merangsang peserta didik untuk belajar menganalisa, berpikir kritis, komunikatif, mampu menyelesaikan masalah, mau bekerja sama, sehingga membentuk karakter peserta didik agar cinta belajar dan menjadikan belajar sebagai gaya hidup (mencintai ilmu). Dengan demikian implementasi neurosains dalam mengembangkan kecerdasan intelektual peserta didik berjalan dengan baik di SD. AL-Azhar BSD sehingga tercipta lingkungan belajar yang ramah terhadap otak anak, dengan rasa nyaman yang terbentuk materi lebih mudah diserap dan berkembang kecerdasan intelektualnya.

Pembelajaran neurosains adalah upaya membuat proses belajar sesuai dengan kerja otak manusia untuk mengoptimalkan hasil belajar. Penerapan pembelajaran neurosains mempertimbangkan tingkat perkembangan otak berdasarkan peserta didik, pada jenjang TK dan SD adalah usia dimana sel-sel otak mengalami pertumbuhan yang sangat pesat meencapai $80 \%$. Rangsangan dari berbagai aktivitas dan lingkungan yang baik akan membentuk karakter yang baik dan melekat sepanjang hayat. Perubahan perilaku dan sikap harus didasari oleh perubahan cara berpikir terlebih dahulu, karena otak manusia selalu berkembang, dan dapat berubah menjadi lebih baik atau lebih buruk. Pendidikan karakter harus menyentuh pikiran bawah sadar yang mengatur kebiasaan emosi, memori jangka panjang, kepribadian, intuisi, kreativitas, persepsi, serta belief dan value. Kreasi dan inovasi guru dalam mengaplikasikan pendidikan karakter akan menjadikan proses belajar di sekolah menjadi menarik dan bermakna sehingga pencapaian hasil belajar bisa seimbang antara ranah kognitif, afektif, dan psikomotorik. Lingkungan fisik sekolah berpengaruh dalam pembentukan karakter peserta didik yang meliputih tatanan sarana dan prasarana sekolah, dan lingkungan sosial seperti teman, guru, dan tenaga kependidikan.

Belajar adalah cara untuk memperoleh sebuah pengetahuan. Belajar seringkali didefinisikan sebagai perubahan yang relatif menetap yang diperoleh dari pengalaman dan latihan. Belajar selalu berkaitan dengan perubahan-perubahan pada diri orang yang belajar, apakah mengarah pada hal yang lebih baik atau sebaliknya. Belajar adalah akivitas (usaha dengan sengaja) yang dapat menghaslkan perubahan berupa kecakapan baru pada diri individu. Belajar dapat pula diartikan semua aktivitas mental atau psikis yang berlangsung interaksi aktif dalam lingkungan, yang menghasilkan perubahan-perubahan dalam pengelolaan pemahaman.

Pembelajaran merupakan suatu proses di mana berbagai pengalaman diberikan dan dialami oleh peserta didik sehingga menghasilkan perubahan yang relatif permanen pada tingkah laku potensial, bila dibandingakan dengan tingkah laku sebelumnya. Perubahan tingkah laku tersebut tidak hanya diindikasikan oleh tingkah laku baru yang nampak, melainkan ada perubahan dalam segi kognitif maupun afektif yang belum atau tidak muncul pada tingkah laku nyata. Hasil belajar yang berupa perubahan tingkah laku tersebut sering disebut prestasi belajar.

Pembelajaran yang dilaksanakan di dalam kelas akan sangat dipengaruhi oleh peran guru dalam membelajarkan peserta didik. Salah satu hambatan dalam mengajar adalah guru mengalami kesulitan dalam menyampaikan materi karena perbedaan inteligensi dari masingmasing peserta didik beserta faktor-faktor lainnya. Disisi lain materi harus disampaikan dan sesuai dengan target pembelajaran namun disisi lain tidak seluruh siswa mampu memahami dan menyerap materi dengan mudah sehingga tujuan dari belajar tidak tercapai secara maksimal. Dalam belajar otak merupakan alat yang mengolah suatu informasi yang kita lihat, dengar ataupun rasakan menjadi sebuah pemahaman. Suatu informasi dapat diterima dan dapat diolah oleh otak sehingga dapat disebut dengan berpikir. Otak adalah faktor yang sangat penting dan

\footnotetext{
${ }^{5}$ Fadhilah Suralaga dan Solicha, Psikologi Pendidikan, Jakarta: Lemlit UIN Syahid, 2010, hal 94.
} 
tidak dapat diabaikan dalam proses mencerna dan memahami materi. Metode sebaik dan semenarik apapun jika tidak memperhatikan kinerja otak tidak akan berlangsung secara optimal. Otak manusia seperti komputer tidak dapat digunakan jika dalam kondisi on. Otak manusiapun tidak dapat menyerap informasi yang masuk, jika otak tidak dalam kondisi on.

Menurut Paul D. Maclean dengan konsepnya triune brain mengatakan bahwa dalam perkembangannya otak dibagi menjadi tiga yaitu otak reptil, otak limbik, dan otak neocortex. Keefektifan belajar erat kaitannya dengan tiga jenis otak manusia yang memproses informasi secara berbeda sesuai dengan stimulus yang diberikan dari lingkungannya. Otak reptil disebut juga sebagai otak sang penjaga. Otak ini terletak paling belakang. Otak reptil berfungsi mengatur gerak refleks dan keseimbangan pada tubuh manusia. Otak inilah yang memerintahkan kita untuk bergerak saat terjadi bahaya ataupun melindungi kita dari bahaya fisik. Otak reptil akan aktif apabila orang merasa takut, stress, terancam marah atau lelah. Pada saat otak reptil aktif, orang tidak dapat berfikir yang berperan adalah insting dan langsung bergerak layaknya sang penjaga yang menjaga pintu gerbang. Otak reptil akan bereaksi (umumnya secara tidak normal), setelah menerima informasi awal dari otak mamalia (yang berfungsi sebagai selector), jika stimulus yang diberikan dari luar tidak menyenangkan. Jika kita dapat memuaskan otak reptil, ia akan membuka pintu masuk arus informasi ke bagian otak berikutnya. Sang penjaga akan terpuaskan jika lingkungan disekelilingnya nyaman. ${ }^{6}$

Selanjutnya otak mamalia atau limbik ini berfungsi sebagai pengendalian emosi, membantu mempertahankan keseimbangan hormonal seperti rasa haus, lapar, pusat kesenangan dan metabolisme. Otak ini untuk melakukan sesuatu melibatkan emosi yang mendalam. Bagian ketiga adalah otak neocortex. Otak ini merupakan $80 \%$ dari otak kita, tugas otak ini adalah berfikir, berbicara, melihat, dan mencipta. Otak ini adalah tempat kecerdasan kita. Neocortex akan memproses informasi (secara normal dan kreatif) juga diterima melalui otak mamalia, jika stimulus dari lingkungannya sangat menyenangkan.

Jadi triune brain adalah saluran informasi, pertama informasi masuk ke otak reptil, apabila otak reptil terpuaskan akan masuk kedalam otak limbik dan apabila otak limbik terpuaskan informasi tersebut dapat diolah oleh otak neokorteks dalam aktivitas berfikir. Namun sebaliknya, apabila otak reptil ridak terpuaskan, maka informasi yang masuk ke dalam otak limbik dan neocortex tidak sempurna sehingga dalam proses berpikir juga tidak sempurna, hal inilah yang membuat materi dalam pembelajaran tidak terserap secara sempurna.

Hal ini juga sejalan dengan Abraham Maslow yang dikenal sebagai pelopor aliran psikologi humanistik. Maslow percaya bahwa manusia tergerak untuk memahami dan menerima dirinya sebisa mungkin. Teorinya yang sangat terkenal adalah teori tentang hierarcy of needs (hirarki kebutuhan). Menurut Maslow, manusia termotivasi untuk memenuhi kebutuhan-kebutuhan hidupnya. Kebutuhan tersebut memiliki tingkatan atau hirarki, mulai dari yang paling rendah (bersifat dasar fisiologis) sampai yang paling tinggi (aktualisasi diri). Dalam teori psikologinya semakin tinggi need maka achievement yang dimiliki seseorang semakin serius ia menggeluti sesuatu. ${ }^{7}$

Bekerjanya otak neocortex inilah yang memberikan banyak kontribusi terhadap keberhasilan dan keaktifan belajar. Otak neocortex tersebut akan mengolah informasi dengan baik dan kemudian menyimpannya dalam otak memori yang nantinya siap dipanggil kembali ketika dibutuhkan saat ujian. Agar neocortex bekerja dengan baik, maka guru sebagai penanggung jawab utama pembelajaran diharapkan dapat memberikan rangsangan yang menyenangkan dan menggembirakan dalam proses pembelajaran.

Ketika peserta didik mendapat rangsangan menyenangkan dari lingkungannya, akan terjadi berbagai 'sentuhan tingkat tinggi pada sistem saraf' yang terjadi pada diri peserta didik

${ }^{6}$ Munif Chatib, Kelasnya Manusia; Memaksimalkan Fungsi Otak Belajar dengan Manajemen Display Kelas, Bandung: Kaifa Learning, 2015, hal 5.

${ }^{7}$ Endang Komara, Belajar dan Pembelajaran Interaktif, Bandung: Refika Aditama, 2016, hal 3. 
yang membuat mereka lebih aktif dan kreatif secara mental dan fisik. Ketika mereka tersenyum atau tertawa aliran darahnya akan semakin lancar menjalar ke seluruh anggota tubuh yang membuatnya semakin aktif. Otak mereka mendapatkan suplai darah yang mengantarkan oksigen yang memadai (ketika tersenyum), hal ini akan memudahkan mereka berpikir dan memproses informasi, baik dalam memori jangka pendek maupun jangka panjang. Informasi yang masuk ke dalam otak memori yang melibatkan emosi secara mendalam, akan memudahkan mereka untuk mengingat kembali saat informasi tersebut diperlukan. Artinya kenyamanan dan kesenangan peserta didik sangat membantu mereka dalam mencapai keberhasilan belajarnya secara optimal. ${ }^{8}$ Jika komputer membutuhkan sofware untuk memproses data, maka otak memerlukan stimulus yang dapat dipakai untuk menghubungkan suatu informasi yang baru diperoleh dengan informasi yang telah dimiliki melalui pengulangan informasi, mempertanyakan informasi atau mengungkapkan kembali informasi. ${ }^{9}$

Yang dimaksud menyenangkan dalam pembelajaran adalah suasana pembelajaran yang memiliki suasana menyenangkan sehingga peserta didik memusatkan perhatiannya secara penuh pada belajar sehingga waktu curah perhatiannya tinggi. Pembelajaran menyenangkan (joyful) perlu dipahami secara luas, bukan hanya berarti selalu diselingi dengan lelucon, banyak bernyanyi atau tepuk tangan meriah. Pembelajaran menyenangkan adalah pembelajaran yang dapat dinikmati oleh peserta didik. Peserta didik merasa nyaman, aman, dan asyik. Perasaan yang mengasyikan mengandung unsur inner motivation yaitu dorongan keingintahuan yang disertai upaya mencari tahu sesuatu. Arti kata menarik yang sesuai dengan konteks ini adalah menyenangkan, menggairahkan hati, menyukakan dan mempengaruhi /membangkitkan hasarat untuk memperhatikan. Dengan demikian, merujuk pada pengertian tersebut, pembelajaran yang menarik hanya mencakup dua unsur yaitu, pertama peserta didik senang, kedua peserta didik memperhatikan.

Selain itu pembelajaran perlu memberikan tantangan kepada peserta didik untuk berpikir, mencoba, dan belajar lebih lanjut, penuh dengan percaya diri dan mandiri untuk mengembangkan potensi diri secara optimal. Dengan demikian, diharapkan kelak peserta didik menjadi manusia yang berkarakter penuh percaya diri, menjadi dirinya sendiri, dan mempunyai kemampuan yang kompetitif. Ciri pokok pembelajaran yang menyenangkan diantaranya:

1. Adanya lingkungan yang rileks, menyenangkan, tidak membuat tegang (stress), aman, menarik, dan tidak membuat peserta didik ragu untuk melakukan sesuatu meskipun keliru untuk mencapai keberhasilan yang tinggi;

2. Terjaminya kesediaan materi pelajaran dan metode yang relevan;

3. Terlibatnya semua indera dan aktivitas otak kiri dan kanan;

4. Adanya situasi belajar yang menantang (challenging) bagi peserta didik untuk berpikir lebih jauh ke depan dan mengeksplorasi materi yang sedang dipelajari;

5. Adanya situasi belajar emosional yang positif ketika para peserta didik belajar bersama, dan ketika ada humor, dorongan semangat, waktu istirahat, dan dukungan yang enthusiast. ${ }^{10}$

Selain pendekatan dan metode dalam belajar guru juga harus mampu memperhatikan aspek intelektual, emosi, dan juga motivasi. Intelektual berperan dalam penentu keberhasilan proses belajar peserta didik. Semakin tinggi kemampuan intelektual peserta didik semakin besar peluang keberhasilan dalam proses pembelajaran. Emosi juga tidak kalah memegang peranan penting dalam belajar. Emosi berpengaruh besar pada kualitas dan kuantitas belajar. Emosi

\footnotetext{
${ }^{8}$ Darmasyah, Strategi Pembelajaran Menyenangkan dengan Humor, Jakarta:Bumi Aksara, 2010, hal 4.

9 Salafudin, Metode Pembelajaran Aktif ala Rasulullah, Pembelajaran yang Membangkitkan Motivasi (Suatu Kajian Metode Pembelajaran dari Hadist), dalam “Jurnal Forum Tarbiyah” Vol 9, No. 2, Desember 2011, hal 198.

${ }_{10}$ Zulfani Sesmiarni, Model Pembelajaran Ramah Otak dalam Implementasi Kurikulum 2013, Bandar Lampung:Aura Publising, 2013, hal 37-38.
} 
yang positif dapat mempercepat proses belajar dan mencapai hasil belajar yang lebih baik, sebaliknya emosi yang negatif dapat memperlambat belajar atau menghentikannya sama sekali. Oleh karena itu, pembelajaran yang berhasil haruslah dimulai dengan menciptakan emosi yang positif pada diri peserta didik. Untuk menciptakan emosi yang positif pada diri peserta didik dapat dilakukan dengan berbagai cara, diantarnya adalah dengan menciptakan lingkungan belajar yang menyenangkan dan dengan penciptaan kegembiraan dalam belajar. Kegembiraan bukan berarti menciptakan suasana kelas yang ribut dan penuh hura-hura. Akan tetapi, kegembiraan berarti bangkitnya pemahaman dan nilai dan nilai yang membahagiakan pada diri peserta didik. Selain itu, dapat juga dilakukan pengembangan kecerdasan emosi pada peserta didik, yaitu kemampuan seseorang dalam mengelola emosinya secara sehat tertutama dalam berhubungan dengan orang lain. Motivasipun memiliki peranan yang penting dalam belajar, seorang guru harus mampu membangkitkan motivasi peserta didik untuk penjadi peserta didik yang mencintai belajar. Sering dijumpai peserta didik yang memiliki intelektual yang tinggi tetapi prestasinya rendah, akibat kemampuan yang dimiliknya kurang berfungsi secara optimal. Dalam hal ini peran motivasi sangat dibutuhkan.

Kemampuan optimal otak manusia menyerap pelajaran hanya 20 menit pertama, setelah itu kemampuannya menurun. Kebanyakan guru tidak memahami hal ini sehingga akan berpengaruh dalam proses pembelajaran. Mereka berbicara di depan kelas lebih dari 50 menit sedangkan kemampuan peserta didik fokus hanya 20 menit pertama. Oleh karena itu dianjurkan setiap 20 menit penyampaian pelajaran, peserta didik diberi waktu untuk istirahat, bergerak, berdiri, atau beraktifitas fisik lainnya karena bergerak memberikan efek positif bagi tubuh, baik fisik maupun mental, termasuk kemampuan kognitif dan emosional. Aktivitas fisik mempunyai pengaruh pada lobus frontalis, suatu area otak untuk konsentrasi mental dan perencanaan. Aktifitas fisik dapat merangsang keluarnya hormon neropinerfin, serotonin, dan dopamine yang memperbarui sel-sel saraf otak sehingga dalam beberapa menit peserta didik bisa kembali duduk menerima pelajaran dengan konsentrasi yang maksimal. Gerak memberi efek positif bagi tubuh, baik fisik maupun mental, termasuk kemampuan kognitif dan emosional.

Dopamin adalah suatu zat kimia yang diproduksi oleh otak tengah (tepatnya di substantia nigra dan VTA). Dopamin sangat berperan dalam proses berpikir (cognitive). Proses berfikir ini sering disebut sebagai kemampuan otak untuk memproses informasi. Dopamin juga berfungsi dalam memotivasi manusia. Motivasi ini bisa berguna untuk hal-hal biologis, seperti makan, hobi, dan motivasi untuk mengejar suatu tujuan tertentu. Zat ini mempunyai peran besar dalam sistem penghargaan (reward system) manusia. Banyak hal yang ada pada kita dipengaruhi oleh dopamin, seperti daya ingat, tidur, perasaan (mood), dan perhatian. Kadar dopamin yang cukup menyebabkan peserta didik akan lebih baik dalam mengembangkan suatu kebiasaan baru dan lebih mudah menyesuaikan diri dengan lingkungan atau penetahuan baru. Kekurangan dopamin dapat mempunyai pengaruh terhadap terjadinya ADD (attention deficit disorder), peserta didk menjadi kurang perhatian atau sulit konsentrasi. Ada suatu kelenjar di otak yang meneghasilkan serotonin fungsi serotonin untuk pengaturan perasaan ( $\mathrm{mood}$ ), pemrosesan daya ingat, tidur, dan proses berpikir. Emosi adalah pengantar informasi. Otak tengah bereaksi positif terhadap emosi positif dan bereaksi negatif terhadap emosi negatif. ${ }^{11}$

Sesungguhnya otak tidak bisa bekerja secara ajaib tanpa melalui proses belajar, tanpa input (masukan) informasi, dan tanpa pengalaman terus menerus sepanjang hayat. Energi informasi bergerak dari dasar otak (otak reptil) melalui pusat emosi atau otak limbik, lalu diteruskan ke bagian atas neokorteks. Kecerdasan adalah kemampuan dalam memecahkan persoalan dan kreativitas yang membutuhkan banyak pengalaman serta pembiasaan dengan jam terbang yang relatif pada setiap peserta didik. Semakin sering kita menghadapi keluhan berupa

11 Hartono Sangkanparan, Otak Tengah Memang Dahsyat ( Bukti-Bukti Dahsyatnya Otak Tengah), Jakarta:Visimedia, 2010, hal 69-70. 
masalah, semakin cepat otak kita merespons untuk mencari solusinya. Namun, semakin tidak terbiasa kita menghadapi masalah, semakin lambat otak kita memberikan solusinya. ${ }^{12}$

Manusia dalam kondisi apapun adalah karya agung Tuhan, masalahnya hanya bagaimana lingkungan memberikan stimulus dan kesempatan yang tepat. Jika lingkungan dalam hal ini guru memberikan stimulus yang tepat maka peserta didik akan memahami, mengerti, dan cerdas. Sebaliknya, jika stimulus yang diberikan tidak tepat maka peserta didik sulit memahami. Kognitif adalah kemampuan olah pikir seseorang untuk mengenali, menganalisis sesuatu, dan akhirnya mampu menyelesaikan masalahnya sendiri. Semestinya, kemempuan kognitif ini tidak terbatas pada kemampuan anak mengerjakan soal-soal tes di atas kertas, namun lebih cenderung pada penyesuaian soal-soal dalam bentuk masalah yang realistis dengan kemampuan berpikirnya. Sayangnya, masih banyak guru yang memberikan soal kognitif tingkat rendah kepada siswanya. Dalam soal-soal kognitif tingkat rendah, tidak terkandung unsur problem. Jenis-jenis soal seperti ini biasanya terdapat pada jenis soal multiple choice atau pilihan ganda materi yang diajarkan. Contoh sederhana adalah soal berikut:

1. $7-2=\ldots$.
a. 6
b. 5
c. 4
d. 3

Perhatikan apakah ada problem nyata pada soal-soal tersebut?

Bandingkan dengan soal sederhana berikut ini: "Pak Reza adalah penjaga peternakan bebek yang berisi 60 ekor bebek. Pada suatu malam, terjadi keributan di kandang bebek tersebut. Ternyata seekor musang menyerang kawanan bebek tersebut. Pagi harinya Pak Reza menemukan 15 ekor bebeknya tewas digigit musang. Ketika harus membuat laporan kepada majikanya, Pak Reza harus menghitung sisa bebek yang masih hidup. Ada berapa ekor yang masih hidup di peternakan?

Pada soal di atas ditemukan perbedaan yang jelas antara kelompok soal pertama dan soal keduanya. Soal mengenai peternakan bebek mengandung problem atau masalah nyata. Inilah yang dimaksud dengan olah pikir kemampuan kognitif peserta didik, harus ada masalah yang dimunculkan dan kemmapuan kognitif akan menjadi problem solvingnya.

Kemampuan mencerna informasi berupa pengetahuan erat kaitannya dengan kerja otak. Otak besar (cerebrum) merupakan bagian paling depan paling menonjol. Proses mengontrol kegiatan berpikir (menerima informasi pelajaran) merupakan tugas dari lobus frontal dan lobus parietal. Sementara keinginan, cita-cita, dan kecenderungan yang kuat diatur oleh lobus frontal. Lobus frontal bertanggung jawab secara penuh untuk kegiatan berpikir, perencanaan, dan penyusunan konsep. Bagian ini berperan penting untuk menatap masa depan persis sama dengan posisisnya yang menghadap ke depan.

Sistem pengajaran memiliki prosedurnya sendiri, yang dikenal dengan istilah rencana pengajaran atau lesson plan. Rencana pengajaran tidak bersifat mutlak dengan nilai validasi sangat fleksibel mengikuti kecenderungan gaya belajar murid. Tidak ada satupun model lesson plan yang paling benar terhadap model lesson plan lainnya. Semuanya dapat dirancang sesuai dengan kondisi belajar murid. Lesson plan tidak bersifat abadi selama bertahun- tahun karena ia bersifat dinamis mengikuti dinamika gaya belajar peserta didik. Hanya saja, satu yang tidak boleh dilakukan guru ketika mengajar, yaitu mengajar tanpa lesson plan.

Bagi guru mendesain sebuah lesson plan sebelum mengajar merupakan sebuah pekerjaan ilmiah, yang memerlukan perilaku ilmiah dan didukung oleh hasil riset. Lesson plan

${ }^{12}$ Munif Chatib dan Alamsyah Said, Sekolah Anak-Anak Juara Bebasis Kecerdasan Jamak dan Pendidikan Berkeadilan, Bandung:PT.Mizan Pustaka, 2012, hal 45. 
merupakan siklus pertama sebuah pembelajaran yang professional dan perencanaan yang dibuat guru sebelum mengajar. Banyak guru pada saat mengajar tidak terlebih dahulu membuat rencana pengajarannya. Guru model ini cenderung asal mengajar sehingga hingga materi selesai boleh jadi, hasil proses pembelajaran yang diperoleh tidak maksimal.

Dalam pengembangan kecerdasan intelektual ada beberapa pendekatan yang bisa digunakan diantaranya pendekatan saintifik, HOTS (higher order thinking skills), literasi, pendidikan karakter, pendekatan pembelajaran kontekstual, kontruktivisme, deduktif-induktif, konsep dan proses, sains, teknologi, dan masyarakat. Pendekatan HOTS, literasi, dan pendidikan karakter seperti yang telah dijelaskan di atas. Pendekatan konstekstual berlatar belakang bahwa peserta didik belajar lebih bermakna dengan melalui kegiatan mengalami sendiri dalam lingkungan alamiah, tidak hanya sekedar mengetahui, mengingat, dan memahami. Pembelajaran tidak hanya berorientasi pada target penguasaan materi, yang akan gagal dalam membekali siswa untuk memecahkan masalah dalam kehidupannya. Dengan demikian proses pembelajaran lebih diutamakan daripada hasil belajar, sehingga guru dituntut untuk merencanakan strategi pembelajaran yang bersifat variatif dengan prinsip membelajarkan dan memberdayakan peserta didik bukan dengan mengajar peserta didik.Dengan menggunakan pendekatan ini peserta didik akan mengalami proses berfikir yang akan meningkatkan daya ingat dan daya nalarnya. Tentunya menggunakan kecerdasan intelelektualnya.

Pendekatan kontruktivisme merupakan landasan berfikir pendekatan kontekstual. Yaitu bahwa pendekatan dibangun oleh manusia sedikit demi sedikit yang hasilnya diperluas melalui konteks yang terbatas dan tidak dengan tiba-tiba. Kelebihan dari teori konstruktivisme ialah peserta didik berpeluang membina pengetahuan secara aktif melalui proses saling pengaruh antara pembelajaran terdahulu dengan pembelajaran terbaru. Pembelajaran terdahulu dikaitkan dengan pembelajaran terbaru. Perakitan tersebut dibina sendiri oleh peserta didik. Menurut teori konstruktivisme, konsep-konsep yang dibina pada struktur kognitif seorang akan berkembang dan berubah apabila ia mendapat pengetahuan atau pengalaman baru.

Pendekatan deduktif ditandai dengan pemaparan konsep, definisi dan istilah-istilah pada bagian awal pembelajaran. Pendekatan deduktif dilandasi oleh suatu pemikiran bahwa proses pembelajaran akan berlangsung dengan baik bila peserta didik telah mengetahui wilayah persoalannya dan konsep dasarnya. Selanjutnya pendekatan induktif memiliki ciri utama dalam pengolahan informasi adalah menggunakan data untuk membangun konsep atau untuk memperoleh pengertian. Data yang digunakan mungkin merupakan data primer atau dapat pula berupa kasus-kasus nyata yang terjadi dilingkungan.

Pembelajaran tradisional adalah pembelajaran dengan pendekatan deduktif, memulai dengan teori-teori dan meningkat ke penerapan teori. Di bidang sains dan teknik dijumpai upaya mencoba pembelajaran dan topik baru yang menyajikan kerangka pengetahuan, menyajikan teori-teori dan rumus dengan sedikit memperhatikan pengetahuan utama, dan kurang atau tidak mengkaitkan dengan pengalaman mereka. Pembelajaran dengan pendekatan deduktif menekankan pada guru mentransfer informasi atau pengetahuan

Pembelajaran dengan menggunakan pendekatan konsep berarti peserta didik dibimbing memahami suatu bahasan melalui pemahaman konsep yang terkandung di dalamnya. Dalam proses pembelajaran tersebut proses penguasaan konsep dan subkonsep yang mencadi fokus. Dengan beberapa metode peserta didik dibimbing untuk memahami konsep. Pada pendekatan proses tujuan utama pembelajaran adalah mengembangkan kemampuan peserta didik dalam hal keterampilan proses seperti mengamati, berhipotesa, merencanakan, menafsirkan, dan mengkomunikasikan. Pendekatan keterampilan. Proses digunakan dan dikembangkan sejak kurikulum 1984. Penggunaan pendekatan proses menuntut keterlibatan langsung peserta didik dalam kegiatan belajar.

National Sciene Teacher Association (NSTA) memandang pendekatan sains, teknologi, dan masyarakat sebagai teaching and learning of sciene in the context of human experience. 
Pendekatan sains, teknologi, dan masyarakat (STM) dipandang sebagai proses pembelajaran yang senantiasa sesuai dengan konteks pengalaman manusia. Dalam pendekatan ini, peserta didik diajak untuk meningkatkan kreativitas, sikap ilmiah, menggunakan konsep dan proses sains dalam kehidupan sehari-hari.

Berdasarkan beberapa paparan di atas maka dapat disimpulkan seluruh guru di SD Islam Al-Azhar telah mengimplementasikan neurosains dalam mengembangkan kecerdasan intelektual peserta didik, hal ini dapat terlihat dari hasil wawancara, studi dokumen, dan observasi peserta didik terlihat antusias, memiliki motivasi tinggi, terlihat senang, dan menikmati proses pembelajaran. dengan mengeta-hui sistem kerja otak maka seorang guru dapat memahami apa saja yang terjadi pada otak peserta didik. Neurosains berguna dalam mengenali tumbuh kembang peserta didik, dan mampu menjadi stimulus untuk mencerdaskan dan mengoptimalisasi kemampuan peserta didik. Manfaat lain mengetahui neurosains adalah dapat mengetahui perilaku abnormal yang terjadi pada peserta didik jika mengalami salah satu penyakit yang disebabkan oleh gangguan sistem saraf. Maka neurosains sangatlah penting karena tugas utama dari neurosains adalah menjelaskan perilaku manusia dari sudut pandang aktivitas yang terjadi di dalam otaknya.

\section{KESIMPULAN}

Berdasarkan hasil penelitian yang telah dijelaskan pada bagian sebelumnya memulai suatu pelajaran tidak bisa langsung terjadi begitu saja tetapi memerlukan upaya stimulasi otak oleh guru kepada peserta didik. Mengingat cara kerja otak yang on dan off seperti komputer, maka sebelum pembelajarn dimulai guru harus mampu mengambil atensi peserta didik terlebih dahulu sebelum memulai pembelajaran sebagai cara untuk mengaktifkan terlebih dahulu otak peserta didik. Atensi atau menarik perhatian peserta didik adalah tindakan dari empat proses kegiatan mental yang kita sebut "belajar". Betapa pentingnya peran otak bagi manusia, karena semua bersumber dari otak. Jaringan sel otak yang bagus adalah otak yang kaya dengan koneksi, berkat rangsangan aktivitas. Kecerdasan intelektual dapat distimulasi secara optimal melalui proses pembelajaran dimana peran guru sangat penting sebagai pemberi stimulus kepada peserta didik. Peserta didik mampu menyerap pelajaran apabila mereka mampu menyerap makna dalam materi akademis yang mereka terima. Guru harus mampu membelajarkan peserta didiknya dengan pembelajaran yang merangsang keaktifan peserta didik dalam belajar. Belajar lebih dari sekedar proses menghafal dan menumpuk ilmu pengetahuan, tetapi bagaimana pengetahuan yang diperolehnya menjadi bermakna untuk peserta didik melalui keterampilan berpikir. Otak yang cerdas meningkatkan kreativitas dan daya cipta baru untuk menemukan hal baru yang tidak pernah terpikirkan. Pembelajaran yang efektif harus dirancang sebaik mungkin untuk mengembangkan kecerdasan intelektual peserta didik. Guru harus mengetahui karakteristik otak pada anak usia dini. Jika tidak mengetahui ini maka akan ada banyak masalah yang ditemui terutama dalam hal stimulasi yang kemungkinan gagal. Stimulasi yang dimaksud adalah bagaimana membuat otak pada anak usia dini memiliki banyak jaringan. Pentingnya stimulasi ini untuk membantu merangsang otak anak sehingga dapat meningkatkan kecerdasannya.

\section{DAFTAR PUSTAKA}

Bungin, Burhan. Metode Penelitian Kualitatif. Depok: PT. Raja Grafindo Persada. 2017.

Chatib, Munif. Kelasnya Manusia; Memaksimalkan Fungsi Otak Belajar dengan Manajemen Display Kelas. Bandung: Kaifa Learning. 2015. dan Alamsyah Said. Sekolah Anak-Anak Juara Bebasis Kecerdasan Jamak dan

Pendidikan Berkeadilan. Bandung:PT.Mizan Pustaka. 2012.

Darmasyah. Strategi Pembelajaran Menyenangkan dengan Humor. Jakarta:Bumi Aksara. 2010. Komara, Endang. Belajar dan Pembelajaran Interaktif. Bandung: Refika Aditama. 2016. 
Mulyana, Deddy. Metodologi Penelitian Kualitatif;cetakan ke VII. Bandung: PT. Remaja Rosdakarya. 2010.

Narbuka, Cholid dan Abu Achmadi. Metodologi Penelitian; cet. VII. Jakarta: Bumi Aksara. 2005.

Salafudin. Metode Pembelajaran Aktif ala Rasulullah, Pembelajaran yang Membangkitkan Motivasi (Suatu Kajian Metode Pembelajaran dari Hadist). dalam "Jurnal Forum Tarbiyah" Vol 9, No. 2, Desember 2011.

Sangkanparan, Hartono. Otak Tengah Memang Dahsyat ( Bukti-Bukti Dahsyatnya Otak Tengah). Jakarta:Visimedia. 2010.

Sesmiarni, Zulfani. Model Pembelajaran Ramah Otak dalam Implementasi Kurikulum 2013. Bandar Lampung:Aura Publising. 2013.

Sugiyono. Metode Penelitian Kuantitatif, Kualitatif, dan R\&D; cet. XIV. Bandung: Alfabeta. 2006.

Suralaga, Fadhilah dan Solicha. Psikologi Pendidikan. Jakarta: Lemlit UIN Syahid. 2010. 